\title{
SEX RATIO IN SHEEP
}

\author{
K. M. NAPIER AND P. D. MULLANEY \\ Department of Agriculture, S. S. Cameron Laboratory, \\ State Research Farm, Werribee, Victoria 3030, Australia
}

(Received 28th Fanuary 1974)

Sex ratios have been the subject of numerous investigations, particularly in studies with humans. In general, however, the literature relating to sex ratio in sheep is limited (Chapman \& Lush, 1932; Henning, 1939; Rasmussen, 1940; Karam, 1957).

Population studies have generally been based on an expected sex ratio of 0.5 , and any factor causing marked divergence from this ratio is important. Although the proportion of entire males used in domestic animal populations in very much smaller than for females, production from castrated males is a significant proportion of the total production of wool and meat from sheep. Hence, studies of population dynamics and flock structure need to take account of factors causing variation in sex ratios.

This paper examines the influence of some factors, breed and strain, age of mother, year of birth and type of birth (single or twin) on the sex ratio of sheep at birth and weaning.

The data used in these analyses were collected as part of a wider study, which has been previously reported (Mullaney, 1966; Mullaney \& Hyland, 1967). Sex ratio at birth was defined as the proportion of males born, either dead or alive; sex ratio at weaning was the proportion of males present at weaning (approximately 150 days of age). Each ewe for each breed (Merino and Corriedale) was classified according to year of birth of offspring, age of ewe, birth type of offspring (single or twin) and strain (property). The method of least squares was used to obtain estimates of the effects of each of these factors on sex ratio at birth and weaning.

The overall sex ratio at birth was 0.508 (11,962 lambs) and at weaning was 0.501 (9746 lambs) (Table 1). These estimates are slightly higher than those quoted previously (Chapman \& Lush, 1932; Henning, 1939; Rasmussen, 1940; Karam, 1957) and are based on larger numbers.

There was a trend for the sex ratio in single births for both breeds to be higher than in twin births $(0.516$ versus 0.489 , Merino; 0.503 versus 0.486 , Corriedale), but this trend was not significant. This supports previous work which suggested a preponderance of females among twin births, probably resulting from differential intrauterine mortality of males in multiple births.

The sex ratio of single lambs decreased at weaning because of the higher survival rate of females $(85.6 \%)$ than of males $(82.4 \%$ ) (Table 2). The survival rate of the two sexes was similar for twin lambs (both $65.7 \%$ ) and the sex ratio of this group remained constant between birth and weaning. Differential 
Table 1. Sex ratio and lamb numbers in Merino and Corriedale sheep

\begin{tabular}{l|c|c|c|c|c|c}
\hline & \multicolumn{3}{|c|}{ At birth } & \multicolumn{3}{c}{ At weaning } \\
\cline { 2 - 7 } & Merino & Corriedale & Both breeds & Merino & Corriedale & Both breeds \\
\hline Total no. of lambs & 7840 & 4122 & 11962 & 6458 & 3288 & 9746 \\
Sex ratio of all lambs* & 0.513 & 0.500 & 0.508 & 0.506 & 0.490 & 0.501 \\
No. of singles & 7009 & 3314 & 10323 & 5915 & 2754 & 8669 \\
Sex ratio of singles* & 0.516 & 0.503 & 0.512 & 0.507 & 0.492 & 0.502 \\
No. of twins & 831 & 808 & 1639 & 543 & 534 & 1077 \\
Sex ratio of twins* & 0.489 & 0.486 & $\mathbf{0 . 4 8 7}$ & 0.495 & 0.479 & 0.487 \\
\hline
\end{tabular}

* Sex ratio $=\frac{\text { Number of males }}{\text { Total of both sexes }}$.

perinatal mortality between sexes has been reported for primiparous species but there is no evidence of this occurring in multiparous species.

Least squares estimates of the effect of year of observation, breed, property and age of dam were not significant for sex ratios, either at birth or weaning. Other reported data have shown that parents of intermediate ages have more

Table 2. Survival rates of Merino and Corriedale lambs from birth to weaning

\begin{tabular}{l|c|c|c}
\hline & Singles & Twins & Total \\
\cline { 2 - 3 } All lambs & 83.97 & $65 \cdot 71$ & $81 \cdot 47$ \\
Merino & 84.39 & 65.34 & $82 \cdot 37$ \\
Corriedale & $83 \cdot 10$ & 66.08 & 79.77 \\
Males & 82.42 & 65.71 & 80.22 \\
Females & 85.62 & 65.71 & $82 \cdot 77$ \\
\hline
\end{tabular}

Values expressed as percentages.

female offspring than older or younger parents (Kamaijaw, 1962; Lowe, 1969; Meadows, 1969). Such effects have however been disputed on statistical grounds (Caughley, 1971) and these data do not show any evidence to support the previous findings.

From this study, there is no evidence that breed or strain of sheep markedly affects sex ratio, but the differential sex ratios that may exist between birth types (single or twin) suggest that current models of population dynamics for sheep may need to be modified to take account of this effect.

\section{REFERENCES}

Gavghley, G. (1971) Offspring sex ratios and age of parents. F. Reprod. Fert. 25, 145.

Chapman, A. P. \& Lush, J. L. (1932) Twinning, sex ratios and genetic variability in the birth weight of sheep. 7. Hered. 23, 473.

Henning, W. L. (1939) Prenatal and postnatal sex ratio in sheep. F. agric. Res. 58, 565.

Kamaijaw, V. S. (1962) Effect of parental age on the sex ratio of offspring. Zh. obshch. Biol. 23, 455.

Karam, H. A. (1957) Multiple birth and sex ratio in Ratimari sheep. F. Anim. Sci. 16, 990.

Lowe, V. P. W. (1969) Population dynamics of the red dear (Cervus elaphus L.) on Rhum. F. Anim. Ecol. 38, 425.

Meadows, B. S. (1969) Sex ratios. New Scient. 44, 476.

Mullaney, P. D. (1966) Pre-natal losses in sheep in Western Victoria. Proc. Aust. Soc. Anim. Prod. 6, 56.

Mullaney, P. D. \& Hyland, P. G. (1967) Reproductive performance of eight wool producing flocks in Western Australia. Aust. F. exp. Agric. Anim. Husb. 7, 304.

Rasmussen, K. (1940) A note on the effect of multiple births on the sex ratio of sheep. Scient. Agric. 21, 759. 